SAKAI SAMBAYAN — Jurnal Pengabdian kepada Masyarakat

\title{
PEMANFAATAN LIMBAH PASAR SEBAGAI PAKAN PADA KELOMPOK TERNAK DAN DIVERSIFIKASI PRODUK OLAHAN ENTOK GUNA MENINGKATKAN PENDAPATAN MASYARAKAT DESA WANADADI BANJARNEGARA
}

\author{
Bahrun Bahrun", Okti Herliana ${ }^{2 *}$ \\ ${ }^{I}$ Jurusan Teknik Ilmu Peternakan Fakultas Peternakan Universitas Jenderal Soedirman \\ ${ }^{2}$ Jurusan Agroteknologi Fakultas Pertanian Universitas Jenderal Sedirman \\ Jl. Dr Soeparno Karangwangkal Purwokerto Jawa Tengah 53122 \\ Jl. Soekarno-Hatta No. 10 Bandar Lampung \\ Penulis Korespodensi : o.herliana@gmail.com
}

\begin{abstract}
Abstrak
Kegiatan Pengabdian Masyrakat Skim Program Kemitraan Masyarakat (PKM) ibi bertujuan untuk melakukan pendampingan bagi kelompok peternak desa Wanadadi Kabupaten Banjarnegara dalam melakukan usaha budidaya ternak mentok dengan memanfaatkan limbah pasar sebagai bahan pakan fermentasi dan memberikan peluang usaha bagi Ibu-ibu PKK dengan melatih mebuat produk makanan berbahan daging entok sehingga diharapkan dapat menambah pendapatan keluarga. Mahalnya harga pakan pakan pabrikan menjadi salah satu kendala dalam kegiatan budidaya entok. Ketersediaan limbah pasar yang melimpah dari pasar desa Wanadadi menjadi salah satu peluang bagi peternak untuk dapat melakukan efisiensi penyediaan pakan ternak. Metodologi yang diambil dalam kegiatan ini adalah Metode PRA (Pratisipasi Rural Appraisal) dimana kelompok sasaran kegiatan terlibat aktif dalam setiap kegiatan. Tahap pelaksanaan kegiatan yaitu: Sosialisasi manfaat limbah pasar sebagai sumber pakan entok, pelatihan pembuatan pakan fermentasi dari limbah pasar, demplot budidaya entok dengan pakan silase limbah pasar, pendampingan kegiatan dan evaluasi pelaksanaan kegiatan. Jumlah peternak yang terlibat dalam kegiatan ini adalah 10 orang. Tingkat keberhasilan kegiatan dinilai berdasarkan hasil evaluasi kegiatan dalam bentuk pretest dan post test. $70 \%$ dari peserta kegiatan dapat memahami materi yang diberikan oleh tim pengabdian, $70 \%$ anggota terampil dalam mengolah limbah pasar sebagai pakan entok fermentasi dan $100 \%$ anggota kelompok ternak mengaplikasikan pakan fermentasi dalam budidaya entok mereka. Secara umum materi dapat terserap dengan baik, terdapat peningkatan ketrampilan peternak dalam membuat pakan dan ketrampilan ibu-ibu PKK dalam membuat makanan olahan berbahan daging entok. Terdapat efiensi biaya produksi ternak entok sehingga pendapatan peternak meningkat.
\end{abstract}

Kata kunci: limbah pasar, entok, pakan, fermentasi

\section{Pendahuluan}

Desa Wanadadi merupakan desa kecil di kabupaten Banjarnegara Jawa Tengah yang terdampak pembangunan PLTA Mrica. Lahan pertanian di Desa ini beralih fungsi menjadi area waduk. Mata Pencaharian Penduduk yang semula sebagian besar sebagai petani beralih pada sektor peternakan, perniagaan di pasar dan buruh. Sekelompok anggota masyarakat mulai mengembangkan usaha bidang peternakan. Kelompok ini menamakan diri Kelompok "Pasar
Ijo 95" awalnya mereka tergerak untuk berwirausaha bidang perikanan, yaitu dengan memelihara ikan nila dan merakit sendiri formula pakan ikan nila, dari pengalaman memelihara dan membuat pakan ikan nila secara mandiri tersebut mereka ingin melebarkan sector kegiatan usaanya dengan beternak mentok dan itik. Melihat permintaan pasar akan daging mentok dan itik yang besar tetapi di pasar Wanadadi belum banyak tersedia maka kelompok ini berusaha ingin memanfaatkan peluang yang ada. Mereka memulai 
dengan skala kecil yaitu memelihara 50 ekor entok. Namun kendala yang dihadapi adalah mahalnya bahan pakan dan bagaimana meramu formulasi pakan yang kaya nutrisi dan hemat. Kendala lain adalah kurangnya minat masyarakat dalam mengkonsumsi daging entok karena kurangnya sosialisasi mengenai produk olahan makanan berbahan entok yang lezat dan bergizi tinggi. Dua hal ini kemudian yang menjadi tantangan bagi tim pengabdian untuk melakukan transfer teknologi dan mendampingi usaha peternak agar lebih maju, efisien dan meningkatkan pendapatan keluarga.

Pasar Desa Wanadadi merupakan salah satu penggerak sektor perekonomian di Desa Wanadadi, Pasar terbesar di Kecamatan Wanadadi sehingga menjadi wadah kegiatan transaksi ekonomi paling ramai di Kecamatan Wanadadi. Kegiatan jual beli, bongkar muat komoditas pertanian terkadang meninmbulkan limbah pasar berupa sampah. Sampah merupakan limbah yang mempunyai banyak dampak pada manusia dan lingkungan antara lain kesehatan, lingkungan, dan sosial ekonomi. Salah satu sampah atau limbah yang banyak terdapat di sekitar kota adalah limbah pasar. Limbah pasar merupakan bahan-bahan hasil sampingan dari kegiatan manusia yang berada di pasar dan banyak mengandung bahan organik. Selama ini pengolahan sampah organik hanya menitikberatkan pada pengolahan sampah organik menjadi pupuk kompos, padahal sampah dapat dikelola menjadi bahan bakar/sumber energi dan pakan ternak yang baik. Hal ini akan lebih bernilai ekonomis dan lebih menguntungkan. Bila sampah organik langsung dikomposkan maka produk yang diperoleh hanya pupuk organik. Namun bila diolah menjadi pakan, sampah tersebut dapat menghasilkan daging pada ternak dan pupuk organik dari kotoran ternak. Dengan demikian nilai tambah yang diperoleh akan lebih tinggi sekaligus dapat memecahkan pencemaran lingkungan dan mengatasi kekurangan pakan ternak.

Penyediaan dan pemberian pakan merupakan salah satu faktor penentu keberhasilan produktivitas ternak. Firdaus et al. (2004), menyatakan bahwa ternak yang dipelihara dengan sistem perkandangan harus dapat memenuhi kebutuhan sejumlah nutrien yang dibutuhkan agar dapat tumbuh dan berkembang. Oleh karena itu Tim Pengabdian Masyarakat Skim Program Kemitraan Masyarakat ini tergerak untuk melaksanakan pendampingan terhadap kelompok peternak Desa Wanadadi agar dapat menjalankan usaha ternaknya dengan baik dan efisien dengan memanfaatkan limbah pasar sebagai pakan fermentasi dan memberikan alternative peluang usaha bagi ibu-ibu PKK dengan melatih pembuatan makanan olahan dari daging entok sehingga tercipta satu usaha terintegrasi antara usaha budidaya ternak entok dan makanan olahan entok.

\section{Bahan dan Metode \\ A. Bahan}

Bahan yang digunakan dalam kegiatan ini adalah limbah pasar (sisa sayuran), dedak molase, EM4, bahan ternak berupa DOD dan Entok remaja, bambou, kayu, paku reng asbes (untuk perbaikan kandang) dan daging entok beserta bumbu-bumbu sebagai bahan dalam membuat makanan olahan berbahan entok seperti abon, rica-rica, entok goreng legit, garang asem, nugget.

\section{B. Metode}

Metode yang diambil dalam kegiatan ini adalah Metode PRA (Pratisipasi Rural Appraisal) dimana kelompok sasaran kegiatan terlibat aktif dalam setiap kegiatan. Tahap pelaksanaan kegiatan yaitu: Sosialisasi manfaat limbah pasar sebagai sumber pakan entok, pelatihan pembuatan pakan fermentasi dari limbah pasar, demplot budidaya entok dengan pakan silase limbah pasar, pendampingan kegiatan dan evaluasi pelaksanaan kegiatan. Jumlah peternak yang terlibat dalam kegiatan ini adalah 10 orang. Tingkat keberhasilan kegiatan dinilai berdasarkan hasil evaluasi kegiatan dalam bentuk pretest dan post test. $70 \%$ dari peserta kegiatan dapat memahami materi yang diberikan oleh tim pengabdian, $70 \%$ anggota terampil dalam mengolah limbah pasar sebagai pakan entok fermentasi dan 100\% anggota kelompok ternak mengaplikasikan pakan fermentasi dalam budidaya entok mereka.

\section{Hasil dan Pembahasan}

Kegiatan pengabdian kepada masyarakat Program kemitraan Masyarakat ini dilaksanakan dengan khalayak sasaran kelompok peternak Pasar Ijo 95 dan Ibu-ibu PKK di Desa/Kecamatan Wanadadi Banjarnegara. Jarak lokasi pengbabdian dengan kampus Universitas Jenderal Soedirman sekitar 56 KM dan waktu tempuh dengan kendaraan bermotor sekitar 1,5 Jam Inisiasi kegiatan di mulai dari rasa keprihatinan terhadap besarnya biaya pakan dalam budidaya entok dan keberadaan limbah pasar berupa sisa 
sayur-mayur yang tidak dimanfaatkan sehingga menimbulkan bertambah besar volume sampah. Berdasarkan studi literatur limbah sayuran di pasar dapat diolah menjadi pakan ternak entok yang berkualitas. Khalayak sasaran terlibat secara aktif dalam setiap kegiatan dan hasilnya dievaluasi berdasarkan capaian fisik, non-fisik serta dampak yang ditimbulkan oleh adanya pelatihan ini, kemudian dianalisis secara deskriptif.

Rangkaian kegiatan Program kemitraan Masyarakat ini dilaksanakan mulai dari sosialisasi, penyampaian materi penyuluhan dan pelatihan yang dilakukan secara umum melalui beberapa tahap, yaitu :

\section{A. Penyuluhan tentang mengolah limbah organik pasar sebagai pakan mentok yang kaya nutrisi dan hemat.}

Materi yang diberikan adalah mengenai budiaya entok, pemeliharaan dan pengolahan limbah pasar sebagai pakan entok yang kaya nutrisi. Ada beberapa jenis limbah sayuran pasar dapat digunakan sebagai pakan ternak unggas diantaranya adalah bayam, kangkung, kubis, kecamba kacang hijau,daun kembang kol,wortel dan lainnya. Limbah sayuran pasar apabila digunakan sebagai bahan baku pakan memiliki beberapa kelebihan yaitu memiliki nilai ekonomis karena dapat menghasilkan beberapa produk yang berguna dan harganya yang murah, mudah didapat dan tidakbersaing dengan kebutuhan manusia. Selain itu juga dapat mengurangi masalah pencemaran lingkungan akibat limbah pasar yang menumpuk. Kelemahan limbahpasar antara lain adalah mudah busuk, voluminous (bulky) dan ketersediaannya berfluktuasi sehingga diperlukan teknologi pengolahan pakan untuk membuat bahan menjadi tahan lama, mudah disimpan dan diberikan pada ternak.

1. B. Pelatihan dan praktek mengolah limbah organik pasar sebagai pakan mentok yang kaya nutrisi dan hemat.

Setelah dilakukan penyuluhan kemudian dilanjutkan dengan pratek membuat pakan entok dengan memanfaatkan limbah sayuran. Bahanbahan yang dibutuhkan untuk membuat pakan, menyusun formula pakan dan menghitung kebutuhan bahan. Alat yang digunakan untuk mendukung pelaksanaan kegiatan yaitu alat tulis, alas plastik, pisau, talenan kayu, baskom plastik, kantong plastik, centong plastik, gilingan daging, ayakan plastik, timbangan, tong plastik. Bahan yang digunakan yaitu ikan rucah, bekatul, sampah organik pasar, molases. Penyuluhan direalisasikan dalam bentuk ceramah dan diskusi, yang dilaksanakan pada siang hari, sebanyak dua kali yang diikuti oleh anggota kelompok wirausaha ternak. Saat praktek membuat pakan mbah organik pasar diikuti oleh seluruh anggota kelompok.

Praktek pengolahan limbah organik pasar dilaksanakan untuk lebih meningkatkan pemahaman peserta secara praktis tentang materi penyuluhan dan dapat mengaplikasikannya secara nyata pada tahap demonstrasi plot. Terdapat dua tahapan dalam pelaksanaan praktek ini, pertama pengenalan alat-alat dan bahan-bahan dilanjutkan dengan praktek proses pengolahan. Praktek dimulai dengan tahapan :

a) Persiapan alat dan bahan (limbah pasar) yang akan digunakan,

b) Pencacahan limbah pasar,

c) Mixing hasil cacahan limbah pasar dengan bekatul, ikan asin dan molases dengan perbandingan $5: 1: 1: 1$,

d) Kemudian digiling,

e) Hasilnya disimpan rapat di tong plastik, difermentasi minimal 3 hari,

f) Setelah disimpan/difermentasikan pakan siap diberikan ke ternak.
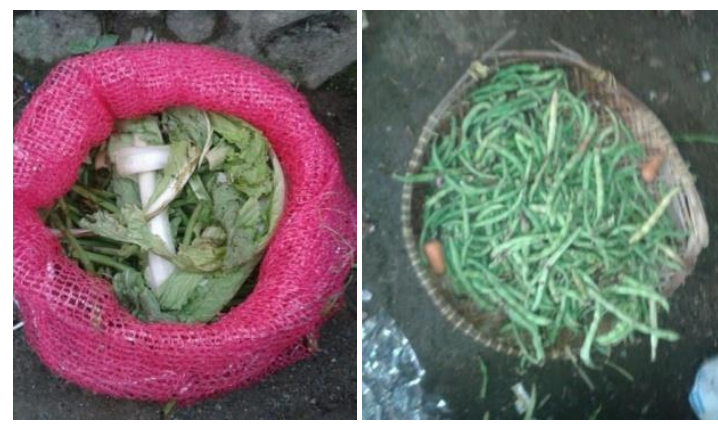

Gambar 1. Limbah pasar yang siap diolah sebagai bahan pakan entok 

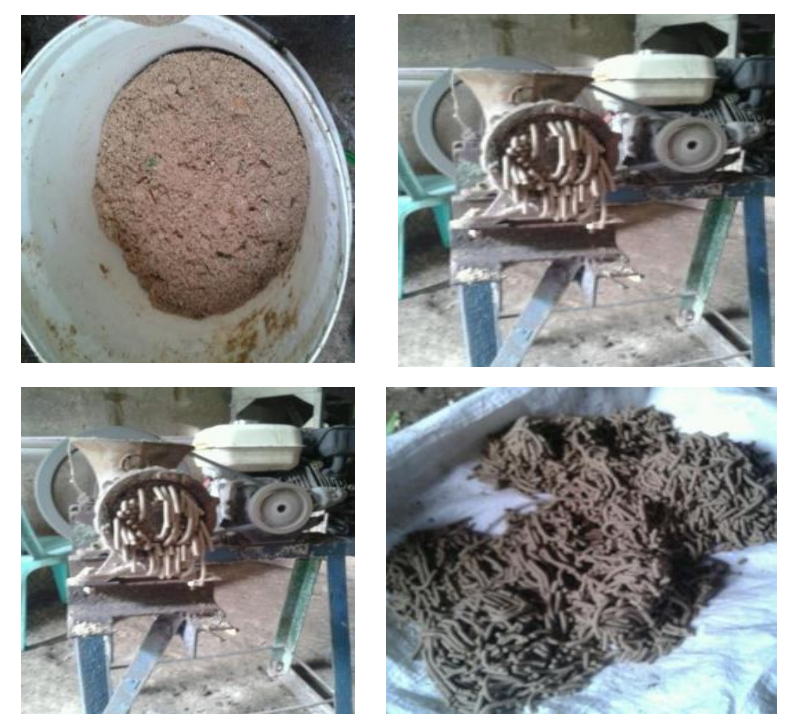

Gambar 2. Proses pengolahan limbah pasar menjadi pakan entok

\section{Demplot pemeliharaan mentok dengan pemberian pakan hasil olahan limbah organik pasar.}

Sebagai implementasi kegiatan alih teknologi dan pelatihan dilaksanakan pembuatan demplot. Tahapannya yaitu rsiapan kandang ternak terdiri dari kandang penetasan, kandang bembesaran, pensucian hama kandang, pembuatan pakan hasil olahan dari limbah organik pasar, pengadaan bibit/dod mentok.

\section{Perbaikan kandang}

Kegiatan ini melibatakan 10 orang anggota indukan. Dari 70 DOD yang dibagikan pada anggota sudah mengalami pertumbuhan dengan peningkatan bobot karkas yang meningkat pesat dengan sumber pakan limbah sayur pasar. Terjadi efisiensi biaya pakan yang cukup signifikan, sehinggat peternak dapat menghemat biaya pakan berikut ini adalah gambar proses distribusi mentok dan peningkatan bobot entok dihitung saat pemeliharaan.
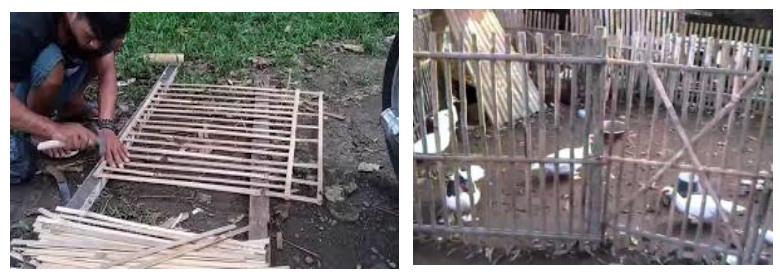
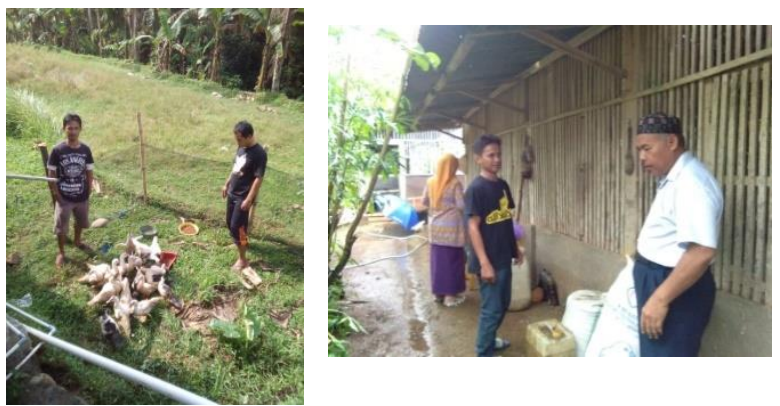

Gambar 3. Kegiatan perbaikan kandang dan distribusi entok

\section{Distribusi mentok}

Setelah kandang pemeliharaan siap kemudian dilakukan kegiatan pengadaan dan distribusi mentok kepada anggota, masing-masing anggota mendapatkan 10 DOD dan 15 buah entok dere/remaja. Distribusi dilakukan dari tanggal 2 Mei 2018 menjelang puasa diharapkan agar hasil panen entok dewasa dapat dilakukan saat menjelang idul fitri dimana konsumsi protein hewani sedang meningkat.. Sebagian entok kawin dan bertelur dijadikan indukan agar jumlah ternak entok terus bertambah. Dari total entok dere berjumlah 105 ekor, sekitar 80 ekor dapat terjual saat idul fitri dan sisanya di jadikan indukan. Dari 70 DOD yang dibagikan pada anggota sudah mengalami pertumbuhan dengan peningkatan bobot karkas yang meningkat pesat dengan sumber pakan limbah sayur pasar. Terjadi efisiensi biaya pakan yang cukup signifikan, sehinggat peternak dapat menghemat biaya pakan berikut ini adalah gambar proses distribusi mentok dan peningkatan bobot entok dihitung saat pemeliharaan.

\section{Penyuluhan pengolahan daging entok menjadi aneka makanan olahan}

Setelah kegiatan pelatihan pembuatan pakan dan demplot terlaksana. Selanjutnya adalah kegiatan introduksi diversifikasi produk olahan entok terhadap mita 2 yaitu ibu-ibu PKK Desa Wanadadi. Entok merupakan jenis unggas yang mempunyai kandungan gizi dan protein cukup tinggi dan tekstur daging lebih mantap sehingga ketika diolah menjadi produk olahan seperti abon, nugget, tongseng, sate dan entok goreng legit teksturnya lebih padat. Introduksi kegiatan olahan makanan entok diharapkan dapat memberikan gambaran usaha alternative bagi kelompok sasaran. Kegiatan ini dikemas dalam bentuk penyuluhan mengenaikandungan gizi pada daging entok, 
kemudian pemberian mater cara pembuatan berbagai macam produk olahan entok dan praktek langsung. Berikut ini adalah gambaran pelaksanaan kegiatannya.

\section{E. Pelatihan dan Praktek pembuatan makanan olahan berbahan daging entok}

Kegiatan penyuluhan produk olahan entok dilanjutkan dengan praktek langsung pembuatan produk olahannya. Contoh produk olahan makanan yang dibuat adalah: tongseng, entok goreng legit, rica-rica, garang asem, abon dan nugget. Kegiatan ini mendatangkan ahli masak untuk mendampingi ibu-ibu PKK dalam membuat produk olahan entok dan dikemas dalam bentuk lomba kreasi penyajian dan rasa. Mitra kegiatan sangat antusias dalam mengikuti rangkaian kegiatan dan melihat peluang usaha olahan entok dapat dijadikan usaha yang dapat menambah pendapatan keluarga. Berikut ini adalah gambar kegiatan pelatihan dan praktek makanan olahan entok.
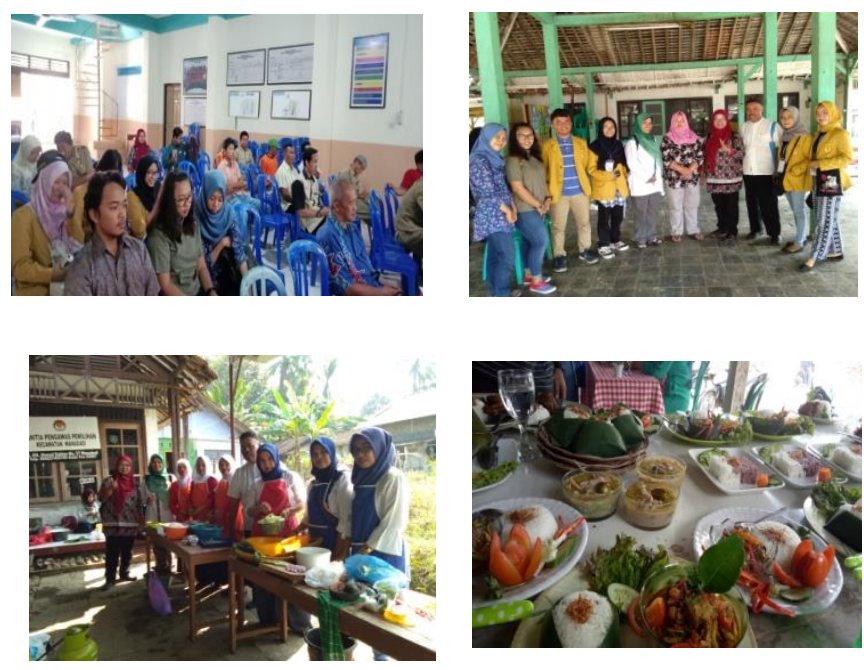

Gambar 4. Pelatihan dan praktek pembuatan makanan olahan berbahan entok

\section{F. Pendampingan dan evaluasi kegiatan}

Keberlanjutan kegiatan pengabdian masyarakat ini adalah pendampingan dan monitoring secara berkala oleh tim. Secara keseluruhan rangkaian kegiatan Pengabdian Program Kemitraan Masyarakat berjalan dengan baik. Hasil evaluasi menunjukkan bahwa penyelenggaraan penyuluhan yang dilakukan dalam bentuk ceramah, diskusi, yang didukung dengan praktek pengolahan pakan, telah mampu meningkatkan pengetahuan peserta sebanyak $70 \%$ peserta. Hal ini dapat dilihat dari adanya peningkatan pemahaman dan keterampilan peserta dalam mengenali dan memilih bahan untuk pengolahan pakan. Dengan demikian dapat dikatakan bahwa materi penyuluhan dapat diterima dan dipahami oleh peserta.

Bagi Ibu-ibu PKK kegiatan pelatihan dan praktek pembuatan makanan olahan berbahan entok memberikan wawasan dan tambahan ketrampilan. Makanan olahan entok menjadi salah satu peluang usaha yang dapat meningkatkan gizi masyarakat dan pendapatan keluarga. Pelatihan penyajian dan kemasan juga menjadi satu bekal untuk memulai satu jenis wirausaha bidang kuliner.

Faktor pendorong yang menunjang keberhasilan pelaksanaan program pengabdian ini antara lain adalah adanya kerjasama yang baik antara tim pengabdi, khalayak sasaran serta dengan aparat setempat. Faktor penghambat dalam menerapkan teknologi ini adalah cuaca, yang sering mendung dan turun hujan, sehingga kegiatan kadang sering terhambat dan harus dijadwal ulang.

Pelaksanaan kegiatan pengabdian kepada masyarakat ini telah dapat terlaksana dengan baik serta berhasil mendidik dan melatih khalayak sasaran menjadi kelompok wirausaha ternak yang lebih inovatif dan mandiri. Selain itu, juga mampu memberikan dampak positif bagi keluarga dan masyarakat disekitarnya, karena dapat mengurangi biaya untuk pembelian pakan serta mampu meningkatkan keindahan dan kebersihan lingkungan.

\section{Kesimpulan}

1. Kegiatan pelatihan tentang Pemanfaatan limbah pasar sebagai pakan entok pada kelompok peternak desa Wandadi dan diversivikasi produk olahan entok pada ibuibu PKK telah terlaksana dengan baik dan lancar. Anggota kelompok dapat terlibat secara aktif dengan seluruh acara yang diselenggarakan.

2. Khalayak sasaran meningkat pengetahuan dan keterampilannya dalam mengelola limbah pasar untuk dibuat pakan unggas. Dan pembuatan makanan olahan berbahan ternak

3. Khalayak sasaran mampu memproduksi pakan buatan dengan memanfaatkan limbah pasar.

4. Pakan hasil olahan telah berhasil 
diaplikasikan untuk pemeliharaan bibit entok dengan menghasilkan pertumbuhan yang optimal, sehingga dapat mengurangi ketergantungan terhadap pakan buatan pabrik yang harganya cukup mahal.

5. Tercipta peluang usaha baru berupa usaha kuliner entok sebagai pemenuhan gizi masyarakat dan meningkatkan pendapatan keluarga

\section{Ucapan Terima Kasih}

Penulis menyampaikan terimakasih pada DRPM DIKTI atas pendanaan pengabdian Program Kemitraan Masyarakat (PKM) ini, LPPM yang telah memberi fasilitas, Masyarakat dan Kepala Desa Wanadadi yang telah berperan aktif dalam kegiatan ini

\section{Daftar Pustaka}

Apriadji, W. H. 1990. Memproses Sampah. Penebar Swadaya Masyarakat. Jakarta.

Anonim. 2013. Budiday entok. http://www.carabudidayasukses.com /2013/06/budidayaentok.

Html Tips. Disitir 25 Oktober 2017.

Budiari, N.L.G., I.M. Raiyasa, I.N. Adijaya, I.A.Parwati, P.A.Kertawirawan, I.M.Sugianyar, I.N.Budiana, I.N. Sutresna dan I.G.A.Astari. 2015. Laporan Akhir Tahun. Kajian Pemanfaatan Keong Mas Untuk Pakan Entok. Balai Pengkajian Teknologi Pertanian Bali. Balai Besar Pengkajian dan Pengembangan Teknologi Pertanian. Badan Penelitian dan Pengembangan Pertanian Kementerian Pertanian.

Disnak Peternakan dan Kesehatan Hewan Propinsi Bali. 2015. Cacah Jiwa Ternak di Propinsi Bali.

Firdaus, D., A. Astuti dan E. Wina. 2004. Pengaruh kondisi fisik kaliandra dan campurannya dengan gamal segar terhadap konsumsi dan kecernaan nutrient pada domba. Jurnal Ilmu Ternak dan Veteriner $9(1): 12-16$.

Hadiwiyoto. 1983. Penanganan dan Pemanfaatan Sampah. Yayasan Indayu, Jakarta.

Marhadi, 2009 Potensi Fermentasi Jerami Padi Sebagai Sumber Pakan Untuk Usaha Penggemukan Sapi Potong. http://marhadi nutrisi 06. blogspot.com/2009/05/jerami.html

Muchtadi, T. R, Ayustaningwarno, F. 2010. Ilmu Pengetahuan Bahan Pangan. Alfabeta.

Bandung

Muktiani, A., B. I. M. Tampubolon dan J. Achmadi. 2006. Potensi Sampah Organik Sebagai Pengganti Rumput Ditinjau dari Parameter Metabolisme Rumen Secra In Vitro dan Kandungan Logam Berat Timbal $(\mathrm{Pb})$. Dalam : Prosiding Seminar Nasional Pengembangan Teknologi Inovatif untuk Mendukung Pembangunan Peternakan Berkelanjutan. Fakultas Peternakan Universitas Jendral Soedirman, Purwokerto. Hal. 108 114.

Muktiani, A., J. Achmadi dan B. I. M. Tampubolon. 2007. Fermentabilitas Rumen Secara In Vitro Terhadap Sampah Sayur Yang Diolah. JPPT., 32 (1) : 44-50.

Nikijuluw, V. 2010. Penghapusan Pajak Pertambahan Nilai (PPN) bagi sekitar 20 Produk Perikanan dan Penunjangnya. (Online). (http://jpmi.or.id/2010/07/31/2010indonesiaimpor-82-juta-kilo-ikansegar-dan-beku/). diakses tanggal 24 Oktober 2017. 
Sembiring, 2006.Biokonversi Limbah Pabrik Minyak Inti Sawit dengan Phanerochaete Chrysosporium dan Implikasinya Terhadap Permormans ayam Broiler. Disertasi Dokter Universitas Padjajaran Bandung.
Sutamihardja, R. T. M. 1978. Kualitas dan pencemaran lingkungan. Laporan Masalah Khusus Jurusan Pengelolaan Sumberdaya Alam dan Lingkungan. Fakultas Pascasarjana. Institut Pertanian Bogor, Bogor.. 